information on judicial decisions in the various countries. The material from countries with a federal structure such as Switzerland, Germany and the United Kingdom hardly takes into account sub-national provisions (Cantons, Länder, etc), so that the legal measures appear incomplete.

Neither book discusses at any length the links and differences between legal provisions and principles of bioethics. The WHO study sees 'self regulation' of research and medical practice in the context of 'professional ethics'. There appears to be a tacit assumption that a legal model of rights protection is more functional than ethical debate and discourse. National legislation on bioethics and the efforts to draft an acceptable European convention on bioethics are further signs of attempts by legislatures and governments to control the debate on bioethics. The risk is that neither Mann's essentially humanistic and optimistic vision of health and human rights, nor pluralistic ethical debate will prevail. The future seems to lie in official regulatory procedures and ever more complex law-making.

PROFESSOR T W HARDING

University of Geneva, Faculty of Medicine, Avenue de Champel, 9, 1211

Geneva 4, Switzerland

\section{The ground of professional ethics}

\section{Daryl Koehn, London and New}

York, Routledge, 1994, 224+x pages, £11.99

Daryl Koehn is a philosopher at DePaul University, Chicago. Her aim in this tightly argued and most readable book is to re-think the source of the standards and norms that shape and inform professional-client relationships. She draws on examples from three different categories of professionals: doctors, lawyers and ministers of religion, and the illuminating way in which she uses her case material suggests that she has had occasion to reflect upon the responsibilities and limits of well-grounded professional action in each of these three categories from within her own life experience. She writes from an American perspective, of course, but this should not deter British readers who will find much to profit by, and several thought-provoking surprises, in following through her analysis.
The book's central proposition is well summarised in the title of Chapter 4: 'The public pledge as the ground of professional authority'. By 'the public pledge' she does not mean making a commitment in public, necessarily, but a pledge by the professional to help any member of the public to the best of his or her ability within a specified area of competence. Her emphasis on an undertaking to render assistance to a clientele distinguishes her position from that of W F May in The Physician's Covenant (1), in which he focuses on the doctor's pledge to an individual patient. It has important implications for the way in which the professional fulfils his pledge, one of which I will touch on in a moment.

However, there is rather more to a well-grounded professional ethic than a promise to serve a client group effectively. Koehn dismisses expertise as a tenable ground for such an ethic. In describing expert knowledge per se as 'inherently untrustworthy' in character (page 20) she is at pains to differentiate it from scientia, theoretical or scientific knowledge applied to the attainment of an object that is good in itself, as are healing, justice and salvation. 'Since the object the professional studies as part of perfecting his own life is the health of the patient or justice for the litigant, the client's good is the professional's object. This good is present "in" the knowledge' (page 21). An analagous argument disposes of a contractual relationship as sure ground, not because a contractual element - or a direct payment for a professional's services - is unethical, but because a contract may undermine the client's trust in the professional, and may induce a passivity in the client that renders the professional's services ineffective.

Professor Koehn's discussion of the nature and limits of confidentiality will be of particular interest to doctors, the more so, perhaps, in that she sheds some new light on the issue by using illustrative examples from the law and the priestly ministry. The prima facie duty of the professional to respect his client's confidence is argued strongly. But duty has its limits, on grounds which are not utilitarian or rightsbased, for reasons cogently set out on pages 165-169, but which rest on the moral dynamic created when the client acts in such a way that she ceases to be a client. The author uses an imaginary example from the confessional to make the point. Suppose a penitent comes to the priest to seek forgiveness for having committed an act of adultery, but in the course of the dialogue reveals that he has contracted a sexually transmitted disease as a result, notwithstanding which he proposes to continue normal sexual relations with his wife without telling her. Although the man genuinely repents his adultery, he shows no remorse over his intention to act in future in a way that may make his spouse ill. This part of his account cannot therefore be said to be a confession, and it would not, under a covenantal ethic, be a protected confidence. The priest has pledged himself to work for the good of a clientele, which in this instance clearly includes the man's wife, whether or not she shares his religious practice, and would therefore be justified in seeking to ensure that she knew about the disease, preferably by persuading her husband that he had a duty to tell her, but in the last resort by informing her directly. Doctors and others who have grappled with the problem of the limits to professional confidentiality, in the context of genetic screening for example, may find matter for reflection in this section of the book.

The centrality of trust and trustworthiness to a professional relationship underlies Koehn's approach to the grounding of professional ethics throughout. Trust must be mutual: a client's role is not a purely passive one, and his willingness to explore his true needs, as distinct from his desires, through dialogue, distinguishes such a relationship from a purely contractual one, where the 'professional's' task is to provide a specified item of service. The cultivation of trust is not a simple matter, not least because each encounter between professional and client is a meeting of two individuals with different backgrounds, different capabilities, and maybe different ideas about the limits of the possible. The author quotes an American legal scholar, writing in 1880: "Duty, not success, is the law of professions"' (page 177). In a world where economic performance and customer satisfaction are assuming ever greater importance in the eyes of policymakers on both sides of the Atlantic, Professor Koehn is right to be concerned about the way in which professional ethics are being undermined, perhaps unintentionally, but none the less damagingly for that. Her attempt to develop a theory that grounds the professional's authority in a coherent and practical way is essential reading for anyone who shares her anxieties. 


\section{Reference}

(1) May W F. The physician's covenant. Louisville, Kentucky USA: The Westminster press, 1983.

CAROLINE MILES

Member, Nuffield Council on Bioethics, Chadlington, Oxfordshire OX7 3NF

\section{Biomedical ethics reviews 1994: allocating health care}

\section{resources}

\author{
Edited by James $M$ Humber and \\ Robert F Almeder, Totowa, New \\ Jersey, Humana Press, 1995, 223 \\ pages, $\$ 44.50$ hard cover
}

Allocating Health Care Resources is a collection of eight essays written mostly by philosophers. This is the twelfth annual volume of Biomedical Ethics Reviews. It addresses various issues surrounding the allocation of health care from the American perspective. The aim of the series is 'to review and update the literature on issues of central importance in bioethics today'. Consequently, the reader should not expect important new questions to be raised or old questions to be covered in new or persuasive ways. But each essay touches upon a number of important issues associated with the allocation of scarce health care resources. The emphasis is on breadth, not depth.

The essays are generally thoughtful and engaging. One of my favourites is George Rainbolt's essay, 'An evaluation of Clinton's health care proposal'. It was written in February 1994, prior to the castration of Clinton's health care reforms. Although it addresses a proposal that has changed considerably, it remains a careful and illuminating examination of the reasons why the cost of health care is so high in the US and what can be done about it. Rainbolt locates the problem in market failure due to: health insurance (which reduces consumers' incentive to care about costs); fee-for-service payment (which give providers an incentive to increase costs); asymmetries of knowledge between consumers and providers; the tax break for health insurance; high administrative costs, and the existence of a closed physician cartel.

More theoretical is Madison Powers's chapter, 'Hypothetical choice approaches to health care allocation'. The most well-known example of this kind of approach is Rawls's procedure, whereby rational self-interested agents choose principles of distribution of social goods from behind a veil of ignorance. But this approach has also been appealed to by utilitarians such as John Harsanyi, and more recently in relation to the distribution of health care by Norman Daniels, Paul Menzel and others. Powers begins by considering the elements common to all hypothetical approaches: counterfactual choice; degree of uncertainty; motivational assumptions, and procedural devices. He then explores some of the difficulties associated with the primary models of Rawls and Harsanyi, Daniels's prudential planner model and the Comparative Benefits Modeling Project. Powers remains sceptical of the place of hypothetical approaches: in particular, they lack action-guidingness because they exclude any reliance on a particular conception of the good. A good chapter dealing with an important issue.

'Rationing, rhetoric and rationality: a review of the health care rationing debate in America and Europe' begins with a discussion of the concept of rationing from the American and European perspectives. The Americans take rationing to be the non-market allocation of resources while the Europeans take it to be denying people medically necessary care. Baker examines the European account based on medical need. He provides a useful division of four kinds of need: expert determination of what constitutes need (England, Canada); community negotiation (Oregon); individual negotiation, and patient demand. This approach is applied to the American health care debate as of March 1994. He closes with an overview of some of the philosophical approaches to rationing, including those of Ronald Dworkin, Norman Daniels, and E Haavi Moreim and briefly discusses other methods of rationing: lottery, triage, excusing and justifying principles and Quality Adjusted Life Years - QALYs.

I looked forward with anticipation to Jeffrey Kahn's 'Sin taxes as a mechanism of health care finance: moral and policy considerations'. I hoped for a saucy justification or rejection of the taxes, but found a workmanlike exploration of the issues and an ambiguous conclusion. Kahn argues that it is justifiable to tax smokers so they pay for the excess costs of their habit (pay their way). Taxation past the break-even point, he argues, must appeal to arguments about the desirability of discouraging 'unhealthful' behaviours and the social good that can be achieved with the revenue. While the alleged subject is ' $\sin$ tax', virtually the whole essay is concerned with 'cigaret' taxes. For those who are unfamiliar with the area, Kahn provides a useful review.

Following their successful past formula, the editors have juxtaposed two essays arguing for opposite claims: Richard Lamm's 'Better health care through rationing' and White and Waithe's 'The ethics of health care rationing as a strategy of cost containment'. Lamm, the former Governor of Colorado, gives a passionate, from the pulpit, call to ration resources. $\mathrm{He}$ argues that it's inevitable, but it's not such a bad thing - we will become more efficient. On the contrary, White and Waithe argue, we are not spending too much on health care, but nonetheless costs can be reduced in other ways. Philosophically, this is one of the most problematic of the pieces. White and Waithe's claim that rationing amounts to an assault on autonomy appears to misunderstand the relationship between autonomy and justice Their use of 'discrimination' appear too broad, and fails to differentiate discrimination from the use of a materias principle of justice. However, both pieces make explicit claims worthy of consideration. I enjoyed both.

In one of the more radical and difficult chapters, 'Health care allocation: a deflationary account', John Douard rejects biomedical models of distribution, which identify health care with personal medical services. He argues that health is influenced by many social factors, of which personal medical care is only one. He builds on the social model of health and disease advocated by Evans and Stoddart. Douard's preferred social model of health care relates health care to well-being (as capabilities and functionings) and positive freedom. The deflationary account of health care involves letting 'the health care system respond to those aspects of health status that are defined as disease by the medical community, but increas[ing] resources for those social problems that seriously jeopardize people's health'.

In 'The injustice of age bias against children in allocating health care', Kopelman illustrates how children are treated by current allocation systems from the perspective of utilitarian, egalitarian, libertarian and contractarian theories of justice.

The strength of this book is the diversity of topics covered. Readers 